\title{
IN VIVO BIOCOMPATIBILITY OF WHITE PORTLAND CEMENT IN MANDIBULAR BONE SURGICAL DEFECT IN RABBITS
}

\author{
Altaib Abdel Razik Mohammed *, Reda Gaber Saleh ** and Naglaa I. Sarhan ${ }^{* * *}$
}

\begin{abstract}
Back ground: white Portland cement (WPC) is a fine powder and most common type of cement in general use around the world. This study was carried out to evaluate in vivo biocompatibility and bone healing efficacy of WPC in surgically mandibular bone defect rabbits.

Material and methods: Fifteen rabbits were divided randomly into three equal groups (I, II\& III). Surgical defect was made at posterior submandibular region on both right and left sides. Sterile WPC powder was applied to the left side defect, while the right side was control. The groups (I, II, III) were sacrificed after 1st, 4th and 8 th week postoperatively respectively. The specimens were processed for light microscope using H\&E and SEM. The newly formed bone filling the defect and cell counting were statistical evaluated..

Results: The experimental sides of all periods revealed increasing in the amount of newly formed bone trabeculae extended from original bone towards the center of the defect. While, the control sides displayed few new bone trabeculae at central area and the lateral wall of the bony defects. The amount of newly formed bone and mean cell counting confirmed the histological results.
\end{abstract}

Conclusion: WPC is a biocompatible osteoconductive economically affordable graft material.

KEYWORDS: Biocompatible, white Portland cement, Mandibular defect, Rabbits.

\section{INTRODUCTION}

Biocompatibility has been described as the ability of a material to perform with an appropriate host response in a specific application. Appropriate host response means no (or a tolerable) adverse reaction of a living system to the presence of such a material ${ }^{1}$. Biocompatible dental materials are the point of interest of many researchers. They have experienced stable progressive growth in developing new products day by day ${ }^{2}$.

\footnotetext{
* Lecturer of Oral and Maxillofacial Surgery Faculty of Oral and Dental Medicine South Valkey University

** Lecturer of Oral Biology, Faculty of Dentistry, Tanta Universty

*** Professor of Histology, Faculty of Medicine, Tanta University
} 
$\mathrm{PC}$ is the most common cement used in civil engineering applications. PC was created and patented in 1824 by an English builder named Joseph Aspdin ${ }^{3}$. The major components of ordinary Portland cement (OPC), which are similar to those of mineral trioxide aggregate (MTA) ${ }^{4}$, consist of tricalcium silicate, dicalcium silicate, tricalcium aluminates, tetra-calcium aluminoferrate, and calcium sulfate dihydrate ${ }^{5}$. There are five types often described as OPC. WPC differs from OPC by its low iron and magnesium, the elements that give cement grey color to $\mathrm{OPC}^{6}$.

Recently the OPC has been analyzed and compared physically, chemically and biologically to MTA. MTA was one of the commonly used biomaterials which was approved for human use by the Food and Drug Administration (FDA) in $1999^{2}$. This material has excellent physical, chemical and biological properties and its ability to induce mineralized tissue promotes it to be used as both a rootend filling and pulp-capping material. However MTA displayed some clinical drawbacks like potential discoloration, prolonged setting time, difficult handling characteristics and being more expensive ${ }^{7}$.

Recent experimental studies have compared the performance of MTA with those of Type OPC and WPC in pulp capping in $\operatorname{dog} s^{8}$, and their effects on the submucosal connective tissue in rats ${ }^{9}$ and subcutaneous connective tissue in guinea pigs ${ }^{10}$. The findings of these studies support the idea that OPC and WPC have the potential to be used in the same clinical applications as MTA. Funteas et al., ${ }^{11}$ concluded in their study that both PC and MTA were identical in their biological effects. at the same time Ribeiro etal., ${ }^{12}$ added that both MTA and PC demonstrated equal behaviors regarding antibacterial properties.

Several in vitro studies concerning the biocompatibility of PC had been conducted and allowing this material to be suitable for medical indications, such as orthopedic and dental application ${ }^{10}$. In another study, Abdullah et. al., ${ }^{13}$ observed that one type of accelerated $\mathrm{PC}$ is non-toxic and may have the potential to promote bone healing in cell culture. While few and limited in vivo studies were conducted concerning the biocompatibility of PC. Campello et. al., observed higher percentage of osteoid and mature bone in experimentally induced traumatic fracture of the mandible of adult rat. Dokami et al ${ }^{4}$ reported that accelerated PC lead to new bone formation in three-walled intra bony defects in dogs. But the in vivo studies of WPC were insufficient to confirm its biocompatibility.

The possibility of using WPC as economically affordable alternative to MTA in dental practice should be considered. Based on all these facts this work was designed to perform an in vivo evaluation of WPC biocompatibility and its capability in healing of mandibular bone surgical defect in adult male Newzealand rabbits.

\section{MATERIAL AND METHODS}

\section{Portland cement:}

Sterile powder of WPC (Oasis White Portland Cement 11/B-L42.Sn Helwan Cement Ital Cement Group Was used in this study .

The cement powdered was sterilized by autoclaving according to Shashikiran et al ${ }^{15}$ at $134 \mathrm{C}^{\circ}$ for 15 minutes in air tight closed bottle

\section{ANIMALS}

Fifteen adult male rabbits of New Zealand breed (4-6 months age) and (2-2.5 kg in weight) were selected and divided randomly into three equal groups (5 rabbits each).This research was designed and carried out according to the guidelines of ethical committee of Faculty of Medicine South Valley University.

\section{Surgical procedures}

The surgery was managed under general anesthesia. Intramuscular atropine sulfate $0.4 \mathrm{ml} /$ $\mathrm{Kg}^{*}$ was used as a premedication 10 minutes before 
injection of mixture of ketamine hydrochloride $10 \%^{* *}$ and xylazin $2 \%$ *at a dose of $0.5,0.2 \mathrm{ml} / \mathrm{Kg}$ body weight respectively I.M. These were injected into the hind limb-thigh muscle ${ }^{16}$. Mepevacaine hydrochloride $2 \%$ with adrenaline * $^{* * * *}$ 1:80,000 also were infiltrated ${ }^{17}$. Animal painless procedures were conducted with appropriate sedation to avoid pain and stress Along the planned surgical site at posterior submandibular region on both right and left site, skin disinfection was carried out using betadine. Subcutaneous incision was made and the tissues were dissected and reflected in layers to expose the inferior border of the mandible (left side) keeping good homeostasis. Surgical defect was designed using surgical bur mounted on high torque low speed surgical motor under continuous irrigation using normal saline. The defect was measuring $8 \mathrm{~mm}$ in length, $3 \mathrm{~mm}$ in width, and $4 \mathrm{~mm}$ in depth just below the inferior alveolar nerve canal, and these measures determined by caliper and width of the used surgical bur. Sterile powder of WPC(The cement powdered was sterilized by autoclaving according to Shashikiran et al ${ }^{15}$ was applied to the defect and the wound closed in layers. The same is done on the right side but without application of the WPC. Antibiotic (oxytetracycline) + and analgesic (ketoprofen) ++ were administered intramuscular to the rabbits for 5 days and free foods were introduced to the animal through the cage. The healing of the wounds was observed daily. The rabbits were sacrificed according to the predetermined period. Groups I, II \& III were sacrificed after $1^{\text {st }}, 4^{\text {th }}$ and $8^{\text {th }}$ week postoperatively respectively. (Figures 1-5)

The bone of the mandible containing the defect on both sides was osteotomized and cut into; one piece was fixed in $10 \%$ buffered formalin for light microscopic study and the other was fixed in $2.5 \%$ glutaraldehyde for scanning electron microscopic study.

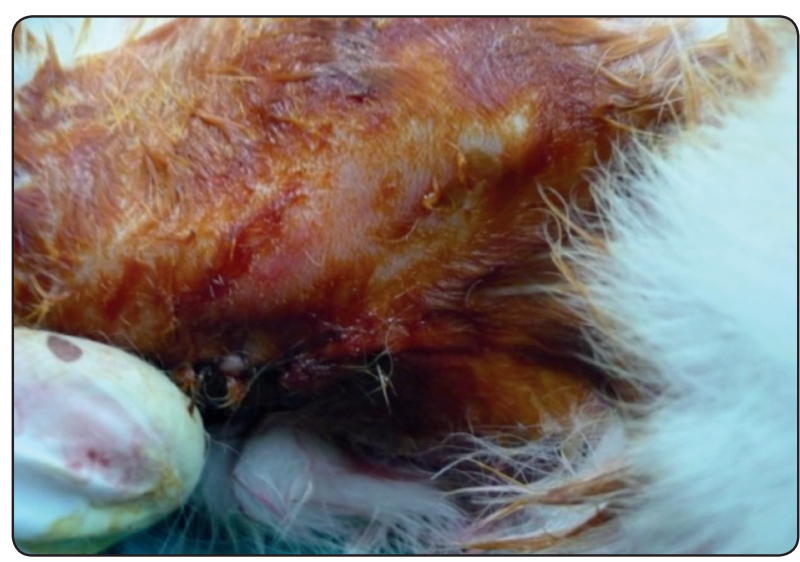

Fig. (1) Disinfection of submandibular region

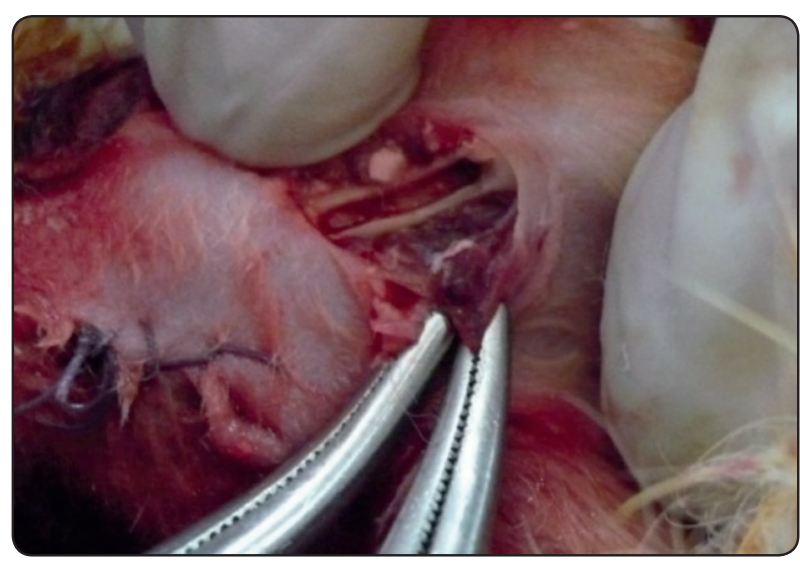

Fig. (2) Standard defect was designed and left empty at right side (quadrangle)

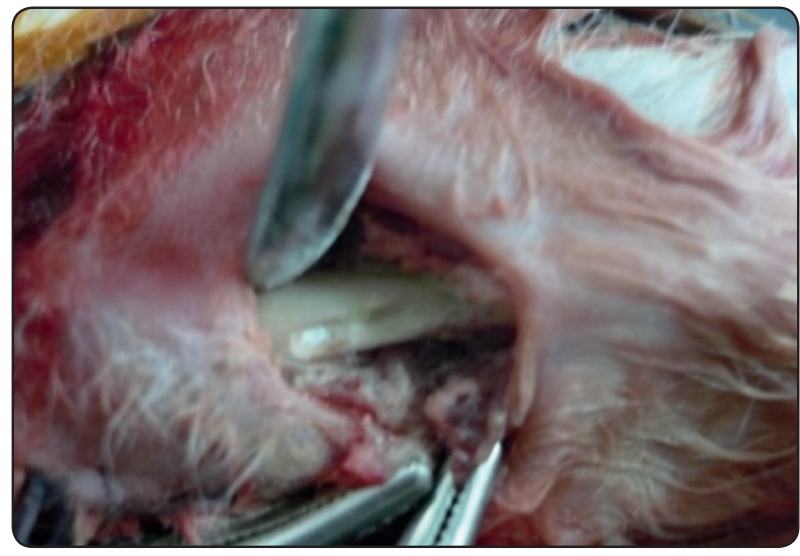

Fig. (3) Disinfection of submandibular region

\footnotetext{
* Atropine sulpate .MEMPHIS ,EGYPT ,,

** ketamine hydrochloride .ROTEX MEDICA TRITTAU .GERMANY

*** XYLA-JECT ADWIA CO,SAE . 10th of Ramadan city .EGYPT

**** Mepevacaine hydrochloride Alexandria CO, EGYPT,

+ spectropan FARMA SWDE EGYPT

++ Bi-Alcofan ALEXANDRIA CO EGYPT
} 


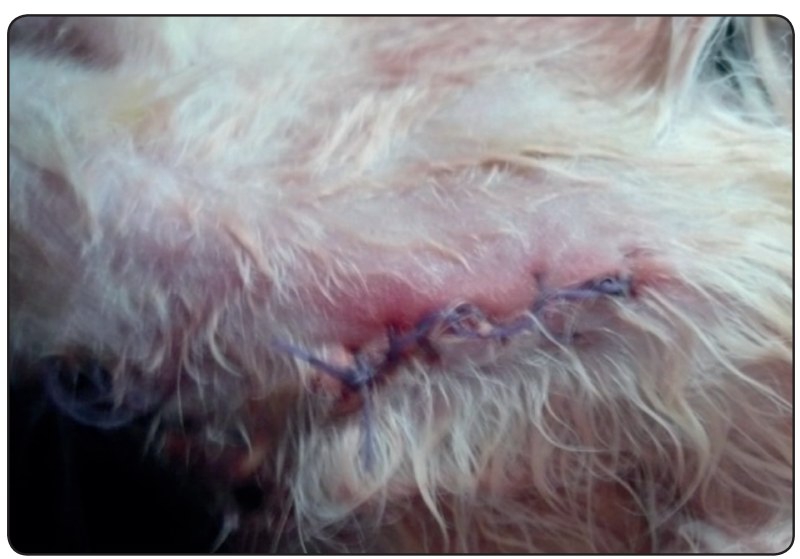

Fig. (4) Closed wound.

\section{Light microscopic study}

Biopsies were fixed in $10 \%$ buffered formalin for $24 \mathrm{~h}$. Specimens were decalcified in 10\% EDTA. The Specimens washed in tap water over night and then dehydrated in ascending grades of alcohol, cleared in xylene and then embedded in low melting point $\left(56^{\circ} \mathrm{C}\right)$ paraffin. Serial sections of $5 \mathrm{um}$ thickness were processed for $H \& E$ stain $^{18}$.

\section{Histomorphometric analysis of newly formed bone filling the defect and statistical evaluation of cell counting:}

After processing and staining, the slides were visualized in a L.M (Leica DM500) equipped with built-in camera (Leica ICC50 HD Camera system). Images of the H\&E stained sections were analyzed for quantitative measurement of newly formed bone and cell counting using the ImageJ analysis system (ImageJ 1.48s, Wayne Rasband, National Institute of Health, USA) ${ }^{19}$.

For the cell counting, the sections were examined by 3 blinded observers, the cell types were identified by their histological based. Highdensity cellular areas were selected and each type of cells (osteoblast, osteoclast and inflammatory cells) was counted in five high power fields at $400 \mathrm{X}$ magnification ${ }^{20}$.

According to the type of inflammatory cells, the inflammatory conditions were classified based on a study by Ørstavik and Mjör: ${ }^{21}$ If there were

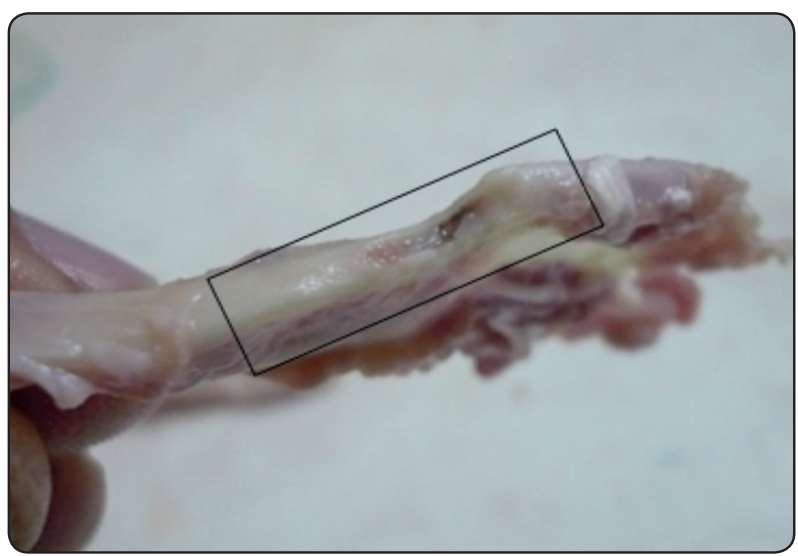

Fig. (5) showing the biopsy of the defect at the lower border (rectangle)

Polymorphonuclear leukocytes (PMNs), it was classified as acute inflammation and if there were lymphocytes, macrophages or plasma cells in this area, it was classified as chronic inflammation.

All statistical analyses were performed using the (ANOVA) followed by t-test in cell counting according to Mould, 198922. All values were expressed as means and standard deviations. All statistical analyses were done on an IBM PC using the statistical software "SPSS 20" (Statistical Package for Scientific Studies) (SPSS Inc., Chicago, Illinois, USA) for windows. Results were expressed in the form probability value ( $\mathrm{p}$-value) that was differentiated into: non-significant when $\mathrm{p}$-value $>0.05$, significant when $\mathrm{p}$-value $\leq 0.05$, highly significant when $p$-value $\leq 0.01$, very highly significant when $\mathrm{p}$-value $\leq 0.001$.

\section{Scanning electron microscope}

The biopsies were fixed in $2-4 \%$ phosphate buffered Glutaraldehyde and formaldehyde $\mathrm{pH}$ 7.3. The specimens were washed twice in buffer to remove any unreacted aldehyde. Post fixation was performed with $0.2 \%$ osmium tetroxide followed by washing in PBS and dehydration in ascending grades of alcohol followed by two washes in acetone. After that the specimens were fixed on stump and coated with gold by sputter coater (Denton Desk II, Denton Vacuum LLC, Moorestown, NJ, USA) ${ }^{23}$ and examined with scanning electron microscope (JSM $5600 \mathrm{LV}$, Jeol, Tokyo, Japan) in EM Unit of central lap of South valley University. 


\section{RESULTS}

\section{Light microscopic results}

\section{Group I ( $1^{\text {st }}$ week $)$}

In the control side, granulation tissue was appeared filling the bony defect in most of the specimens. Newly formed osteoid tissue lining the wall of the defect in some areas and separated from the old bone by reversal line was observed.
Other areas showed excessive osteoclastic activity (Figure 6).

In the experimental side, newly formed bone trabeculae were observed separated from the old bone by reversal line. They extended on a radiating manner from the old bone surface toward the center of the bony defect. Graft material was surrounded by moderate inflamed high cellular CT with collagen fibers and bone spicules (Figure 7).

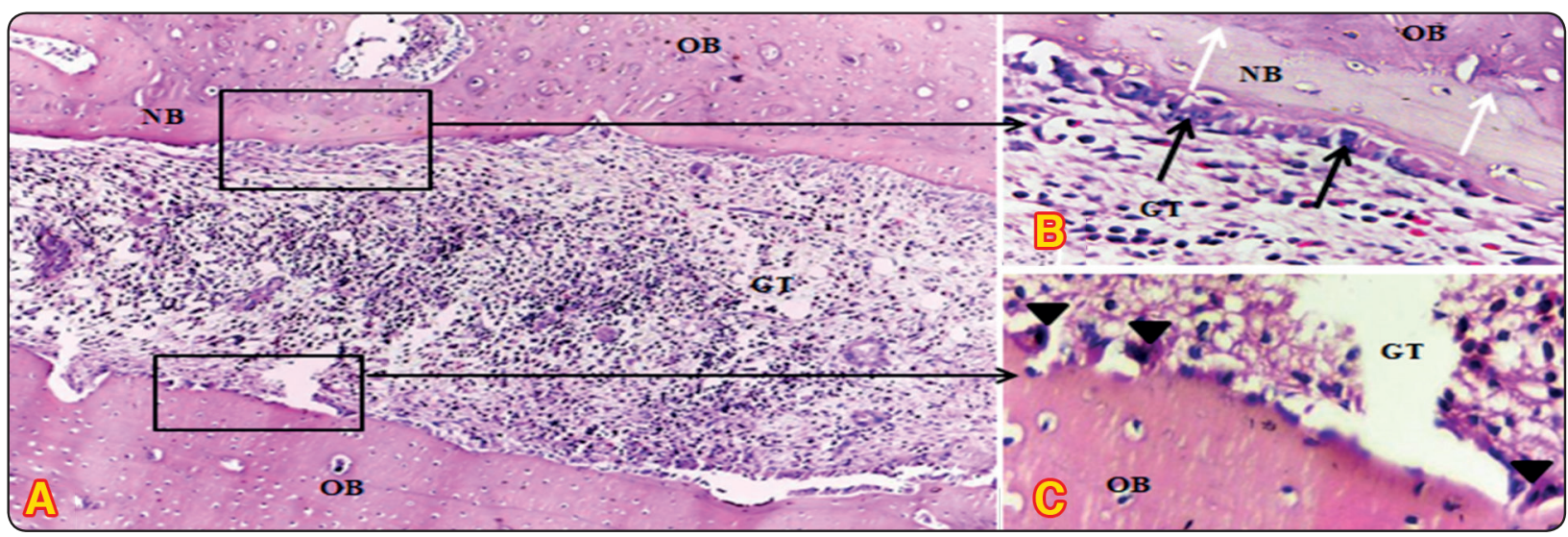

Fig. (6) Photographs of a group I (control side) showing. A. Moderate inflammatory cell infiltration of the granulation tissue (GT) filling the bony defect, with newly formed bone (NB) lining the wall of the bony defect in some areas. B. (Higher magnification of figure A) Reversal line (white arrow) separate between old bone (OB) and NB, active osteoblast (black arrow) lining the NB. C. (Higher magnification of figure A) Active osteoclast (arrow head) attached to the OB. (H\&E orig. mag., $\mathbf{A} \times 10, \mathbf{B} \& \mathbf{C} \times 40)$.

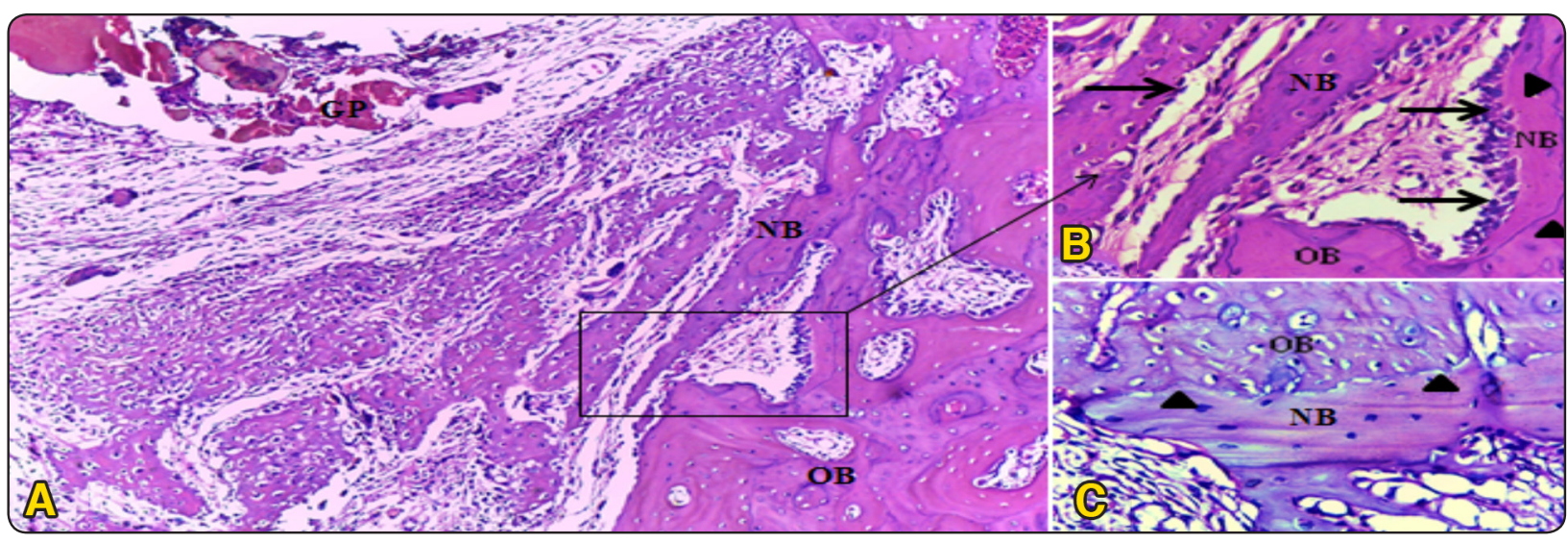

Fig. (7) Photographs of a group I (experimental side) showing. A. Moderate inflammatory cell infiltration in the C.T surrounding the graft particles (GP), with newly formed bone trabeculae (NB) at the base and lateral wall of the bony defect. Both B. (Higher magnification of figure A) \& C. show reversal line (arrow head) separating old bone (OB) from NB and active osteoblast (arrow) lining the NB. (H\&E orig. mag., $\mathbf{A} \times 10, \mathbf{B} \& \mathbf{C} \times 40$ ). 


\section{Group II (4th week)}

In the control side, few new bone trabeculae were observed at central area and the lateral wall of the bony defect, they were lined by active osteoblast with areas of osteoclastic activity. Large areas of CT were noticed filled with large blood vessels. There were large areas of fat tissue (Figure 8).
In the experimental side, will organized bone trabecula were observed filling large areas of the bony defect, they were lined by active osteoblasts. Large bone marrows were noticed filled with C.T and large blood vessels. Most of the graft material was disappeared except small remnant (Figure 9).

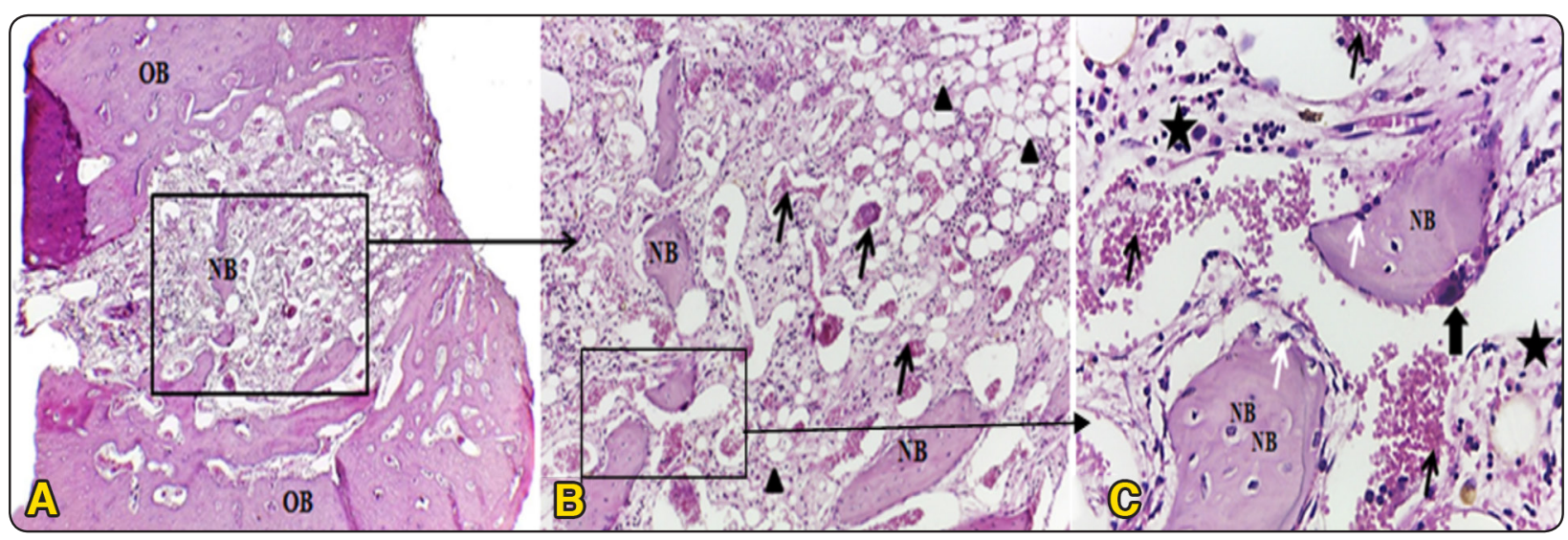

Fig. (8) Photographs of a group II (control side) showing. A. Few newly formed bone trabecula (NB) at the center and lateral wall of the bony defect. B. (Higher magnification of figure A) Few NB trabeculae surrounded by CT and large blood vessels (thin black arrow), and areas of fat tissue (arrow head) were seen. C. (Higher magnification of figure B) The NB lined by active osteoblast (white arrow). Large areas of CT (star) filled with large blood vessels (thin black arrow). Active osteoclast attached to the NB (thick black arrow). (H\&E orig. mag., $\mathbf{A} \times 4, \mathbf{B} \times 10 \& \mathbf{C} \times 40$ ).

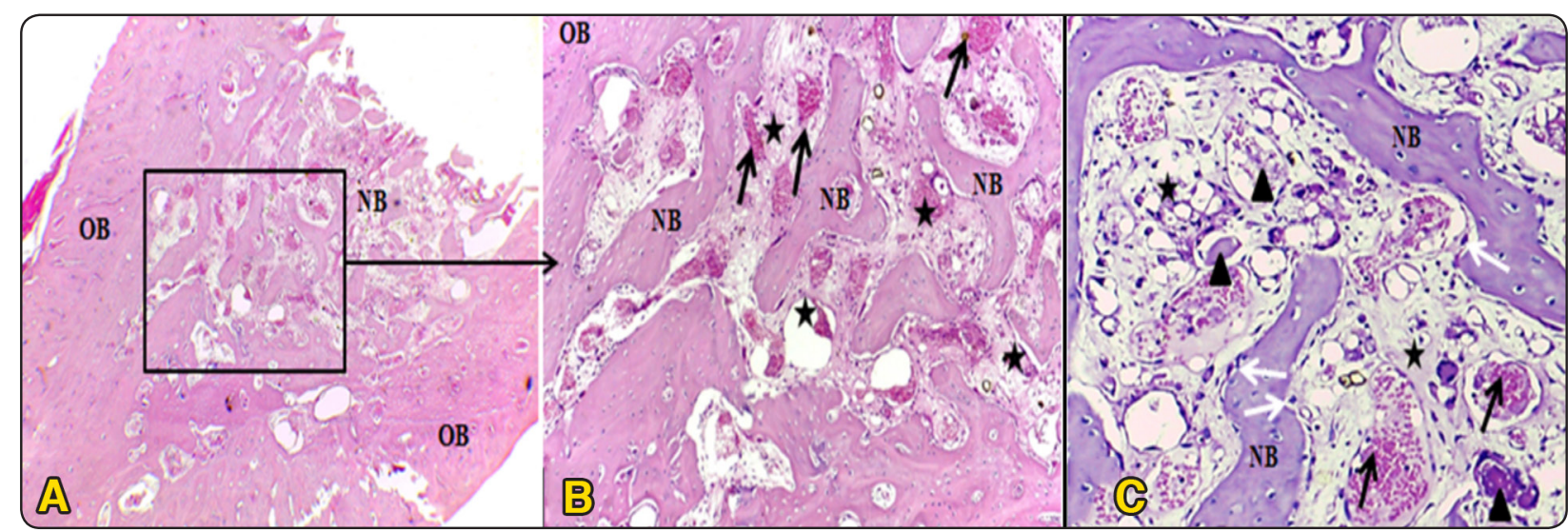

Fig. (9) Photographs of a group II (experimental side) showing. A. Well organized newly formed bone trabeculae (NB) were observed filling large areas of the bony defect. B. (Higher magnification of figure A) Large bone marrows (star) filled with CT and large blood vessels (black arrow). C. New bone trabecula (NB) lined by active osteoblast (white arrow), large bone marrows (star) filled with CT and large blood vessels (black arrow), remnant of graft material (arrow head) was appeared. (H\&E orig. mag., $\mathbf{A} \times 4, \mathbf{B} \times 10 \& \mathbf{C} \times 40)$. 


\section{Group III ( $8^{\text {th }}$ week $)$}

In the control side, few bone trabeculae were observed filling central area of the bony defect. They were appeared surrounded by fibrous tissue. Rest of the defect filled with C.T with multiple areas of fat tissue (Figure 10).

In the experimental side, will organized thick mature, well-connected bone trabecula were observed filling large areas of the bony defect starting from the lateral walls to the center of the defect, they were appeared surrounding variable sizes of bone marrow cavities. The mature bone trabecula contained mature osteocytes in their lacunae with reversal lines. (Figure 11).

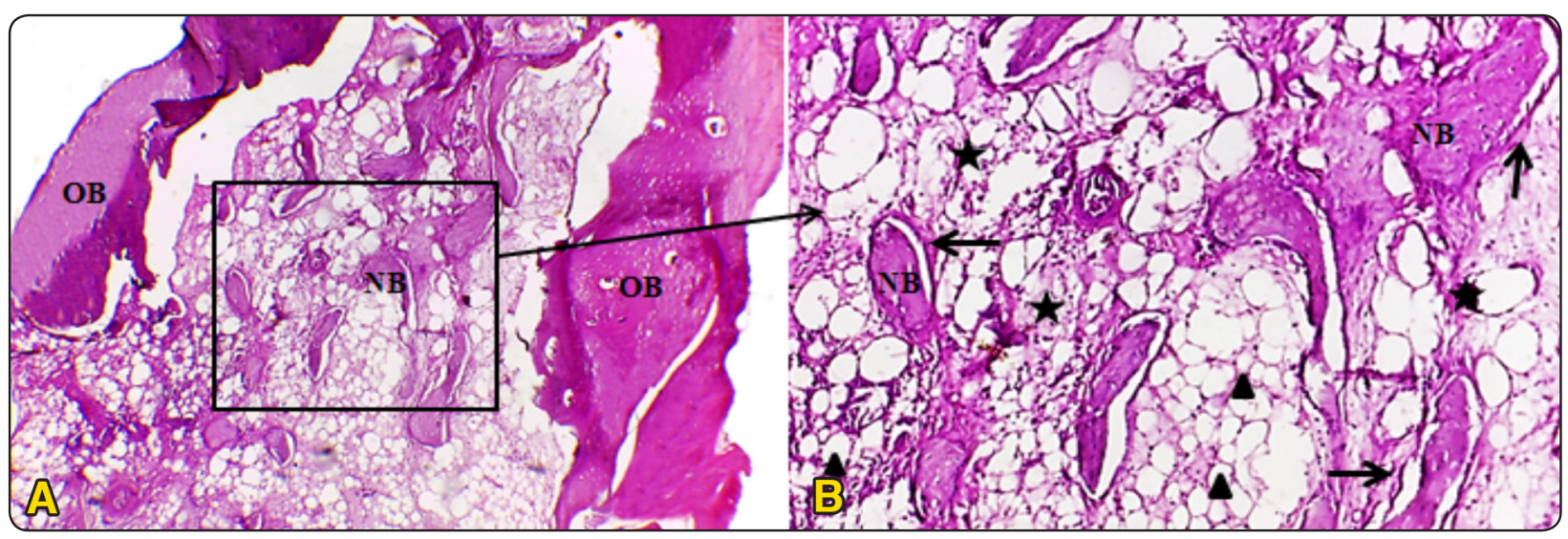

Fig. (10) Photographs of a group III (control side) showing. A. Few bone trabecula (NB) at the center of the bony defect. (Higher magnification of figure A) Few NB surrounded by fibrous tissue (arrow), and areas of fat tissue (arrow head) was appeared. The NB surrounded by large areas of CT (star). (H\&E orig. mag., $\mathbf{A} \times 4, \mathbf{B} \times 10$ ).

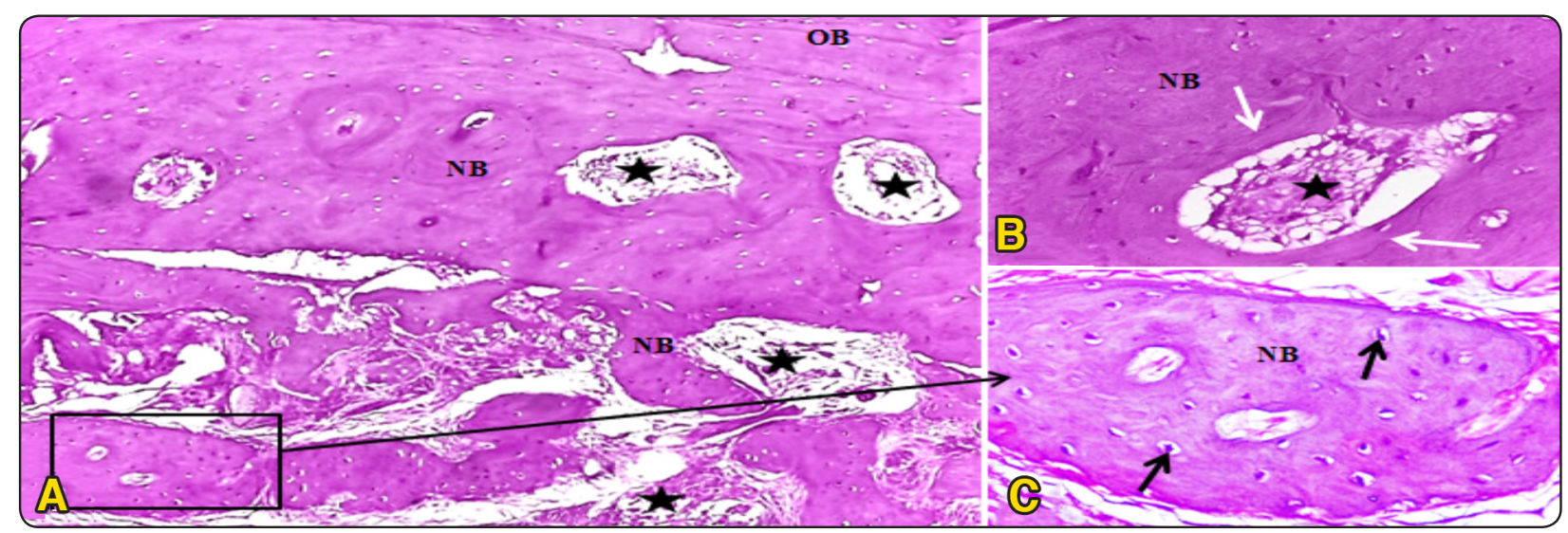

Fig. (11) Photographs of a group III (experimental side) showing. A. Well organized large mature bone trabecula (NB) were observed filling large areas of the bony defect, the most mature one near the old bone (OB), with variable sizes of bone marrow cavities (star). B. Higher magnification of mature bone trabecula with large Harversian canal (star) and reversal line (white arrow). C. (Higher magnification of figure A) New bone trabecula (NB) with mature osteocytes in their lacunae (black arrow). (H\&E orig. mag., $\mathbf{A} \times 10, \mathbf{B} \& \mathbf{C} \times 40)$. 


\section{Scanning electron microscopic results}

The portland cement presented porous electron lucent variables sized granules loosely connected with each other (figure 12)

\section{Group I ( $1^{\text {st }}$ week $)$}

Control side showed persistence of a wide cavity in the bone defect with irregular edges in association with thick irregular bone trabeculae and bone marrow cavities. Wide separation line between the original bone and old bone was seen. New bone was observed lining some localized areas at the edge of the defect. (Figure.13)

Experimental side displayed graft material in the middle with new bone formation lining the cavity. Union of the old bone with new one at several points traversing the line of separation was observed. The centre of the cavity showed newly formed bone trabeculae, branched blood vessel and globular calcification. The cavity area appeared filled with fused amalgamated graft material and depicted formation of thick irregular bone trabeculae with irregular cavities in between. (Figure.14)

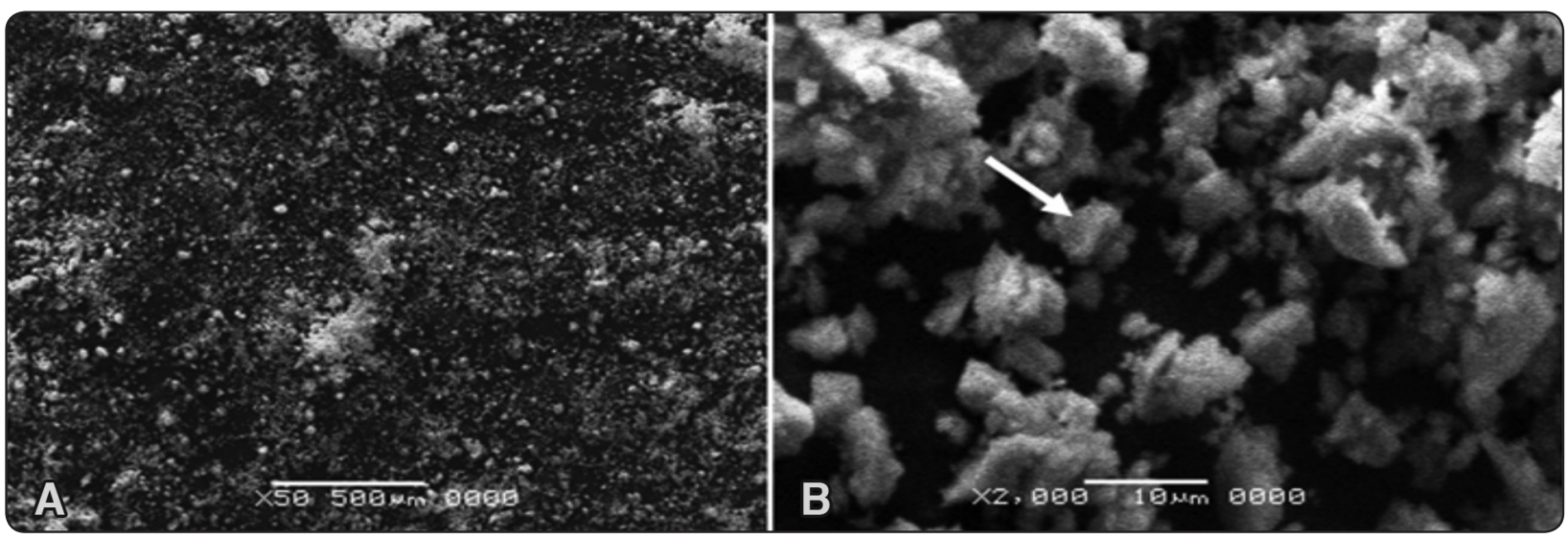

Fig. (12) Scanning electron micrograph of WPC shows porous electron lucent variable sized granules loosely connected with each (arrow). (Ax50 \& Bx2500)
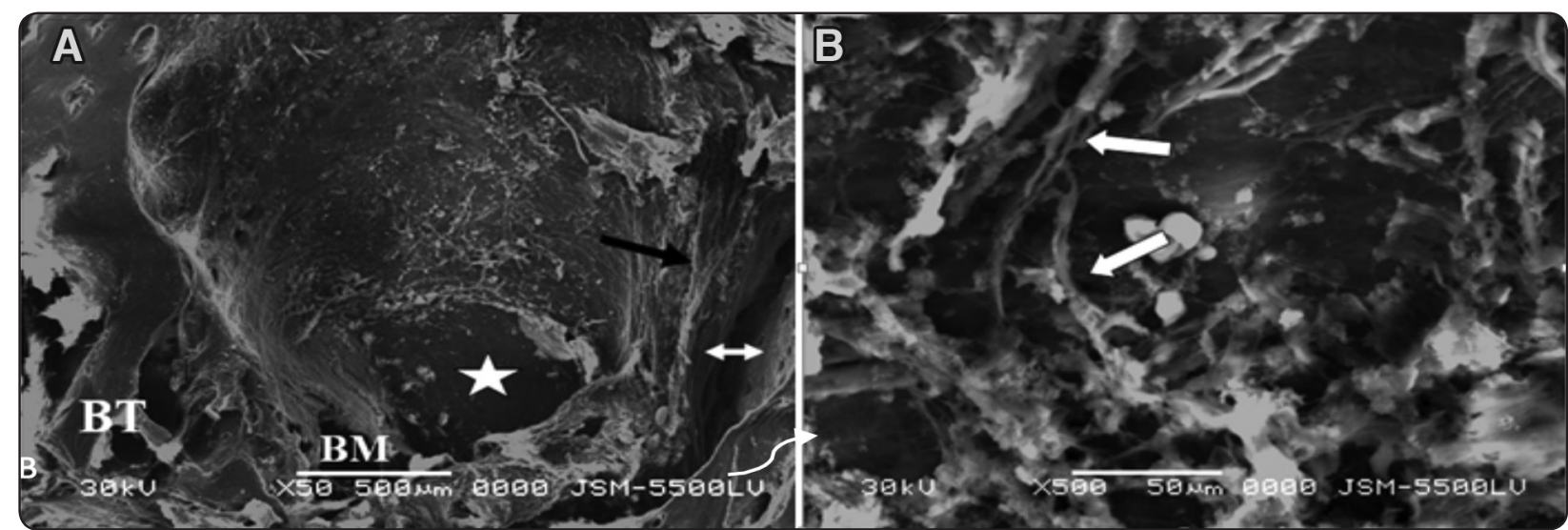

Fig. (13) Scanning electron micrograph of control side; A. shows the base of the bone defect with wide cavity in the centre $(*)$ bounded by thick irregular edges (arrow) in association with thick irregular bone trabeculae (BT) and bone marrow cavities (BM)present in between. Notice separation line (double head arrow) .B. shows fibrous tissue (thick arrow) in the floor of the cavity. (A x50 \&Bx500). 


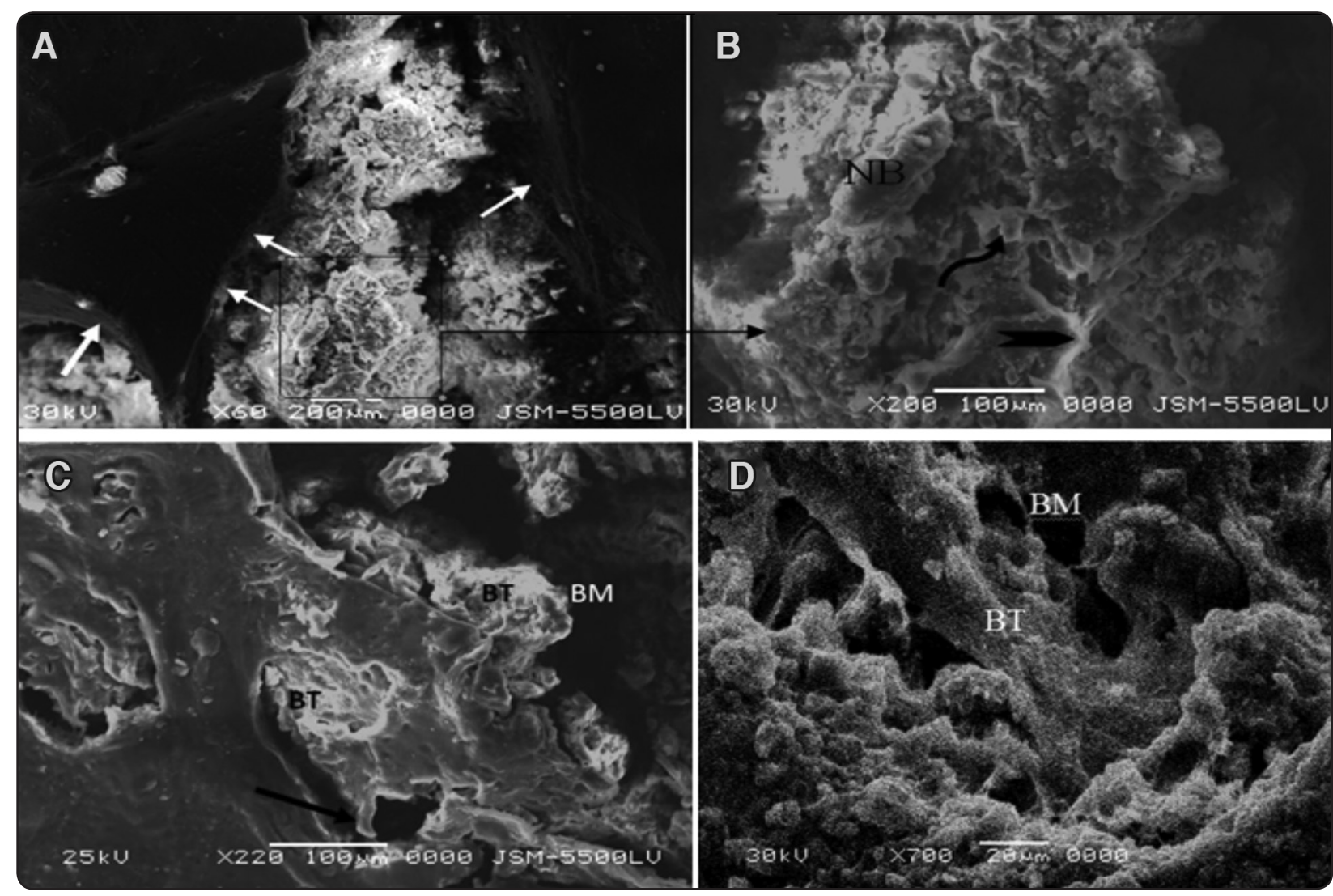

Fig. (14) Scanning electron micrograph of experimental site; A. shows the graft material in the middle with new bone lining the cavity (white arrow). Notice osseointegration of the old bone with new one at several points traversing the line of separation (black arrow). B. Higher magnification of the previous field shows the center of the cavity containing newly formed bone trabeculae (NB), branched blood vessel (notched arrow) and globular calcification (wavy arrow). C. showing newly formed bone trabeculae (BT)and spicules (arrow) extending on the surface of the original bone. Note large bone marrow cavities (BM).D. shows newly formed thick irregular bone trabeculae (BT )at the porous structure of the graft material with irregular cavities (BM)present between the trabeculae (A x 60, B x200, Cx150 \& Dx700).

\section{Group II ( $4^{\text {th }}$ week $)$}

Control side revealed large cavity with smooth edges and the wall of the bone defect filled with irregular and incomplete short bone trabeculae (trabecular like growth) observed near the original bone with bone marrow cavities in-between. Fibrous tissue was seen filling the floor of the cavity (Figure.15).
Experimental side displayed the edges of the bone defect and newly formed bone trabeculae extending from the internal surface of the original bone towards the centre of bone defect in association with replacement of the graft material with immature bone. Thick irregular bone arm was seen extending from the original bone towards the centre of bone defect. Bone marrow cavities with formation of multiple vascular channels were also observed. Red blood cells were seen in between.(Figure.16). 


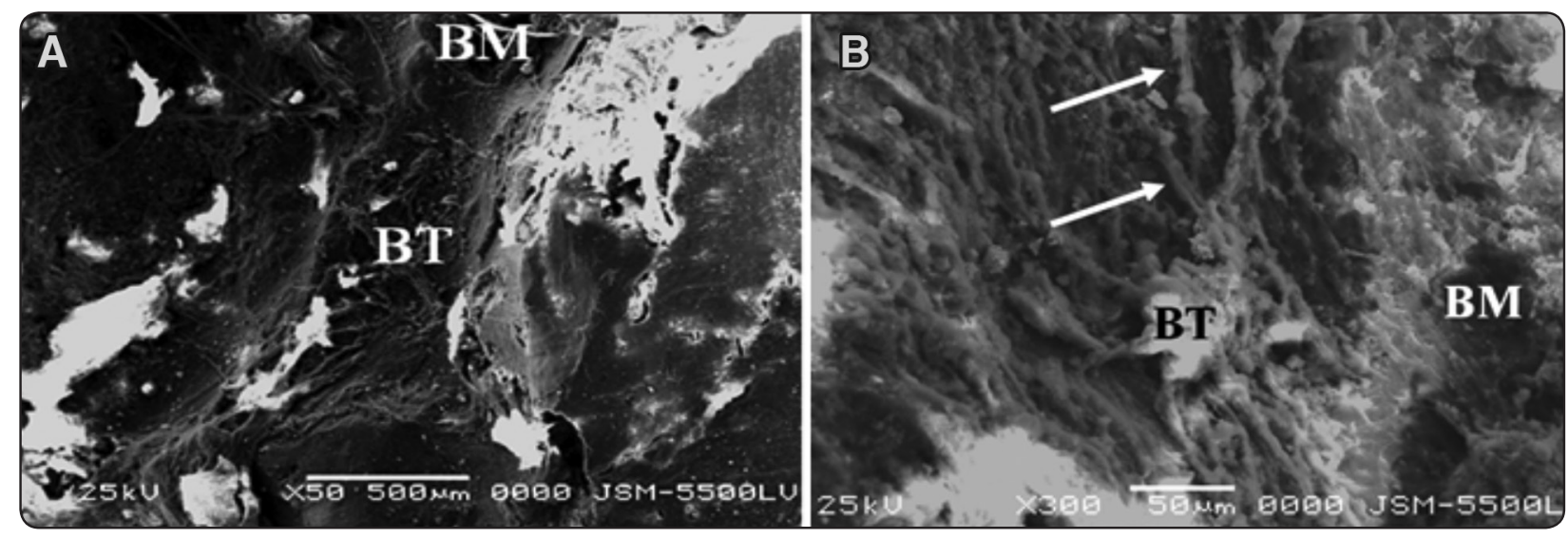

Figure (15) Scanning electron micrograph of control side. A shows the wall of the cavity of the bone defect filled with short irregular bone trabeculae (BT) with multiple bone marrow cavities (BM). B (Higher magnification of figure A) showing the floor of the cavity filled with newly formed bone trabeculae (BT) with multiple bone marrow cavities (BM) in association with fibrous tissue (arrow). (Ax50\& B X300).

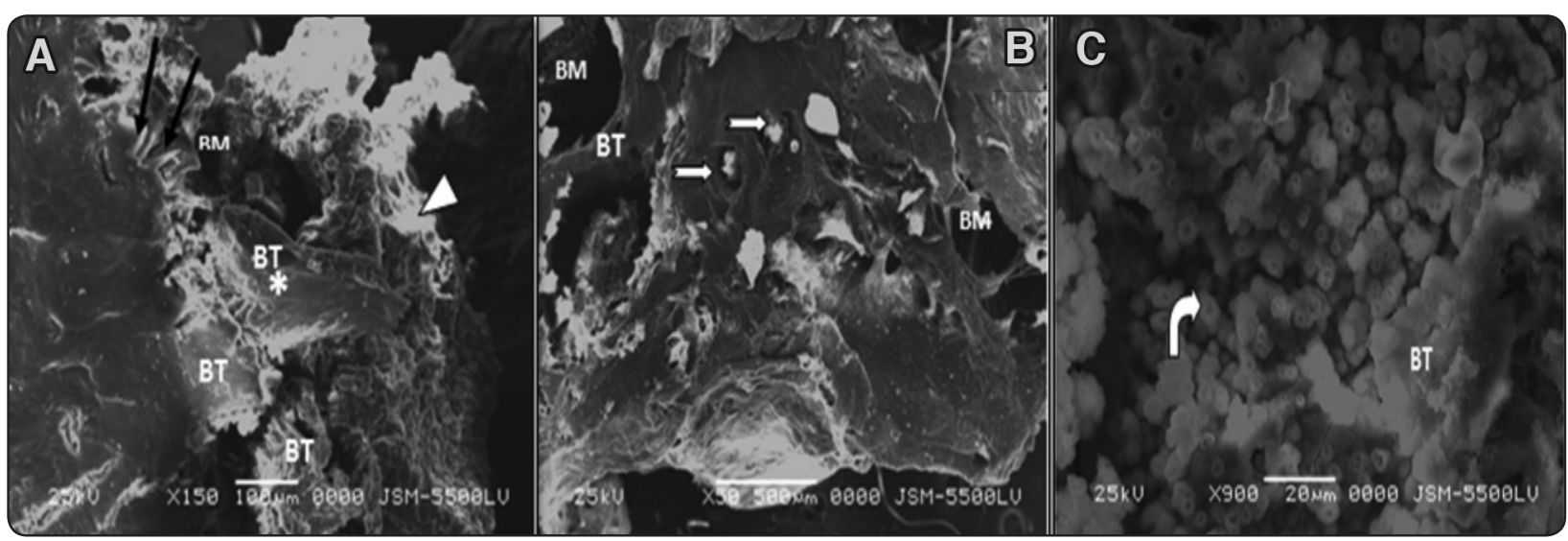

Figure (16) Scanning electron micrograph of experimental side of group II: A shows the edges of bone defect with newly formed bone evidenced by thick irregular bone trabeculae (BT) or thin bone spike or bone arm extending from its internal surface towards the centre (arrow) in addition to long arm of bone extending from the original bone towards the centre of bone defect $(*)$ Replacement of the graft material with immature bone was also observed (arrow head) .B shows thick newly formed bone trabeculae (BT), bone marrow cavities (BM) and multiple vascular channels formation (notched arrow) (Haversian canals ).C shows newly formed bone trabeculae (BT) with red blood cells in-between (curved arrow). (A x150, B x50, Cx900). NB can revise this figure for the second time

\section{Group III $\left(8^{\text {th }}\right.$ week $)$}

The control side revealed healing and filling of the defect with fibrous tissue. However few fields depicted globular calcification and incomplete closure of the surgical site with partial integration of newly formed bone with the original one. The newly formed bone was evidenced by thick irregular bone trabeculae with multiple bone marrow cavities in between. Persistence of wide irregular areas of bone defect were still observed( Figure. 17).

Experimental side showed complete filling of the defect and disappearance of the graft material and its replacement with bone with absence of demarcation line. Globular calcification is one of the prominent finding. Multiple irregular thick bone trabeculae of varying thickness and bone marrow cavities were observed filling the bone defect with globular calcification (Figure.18). 


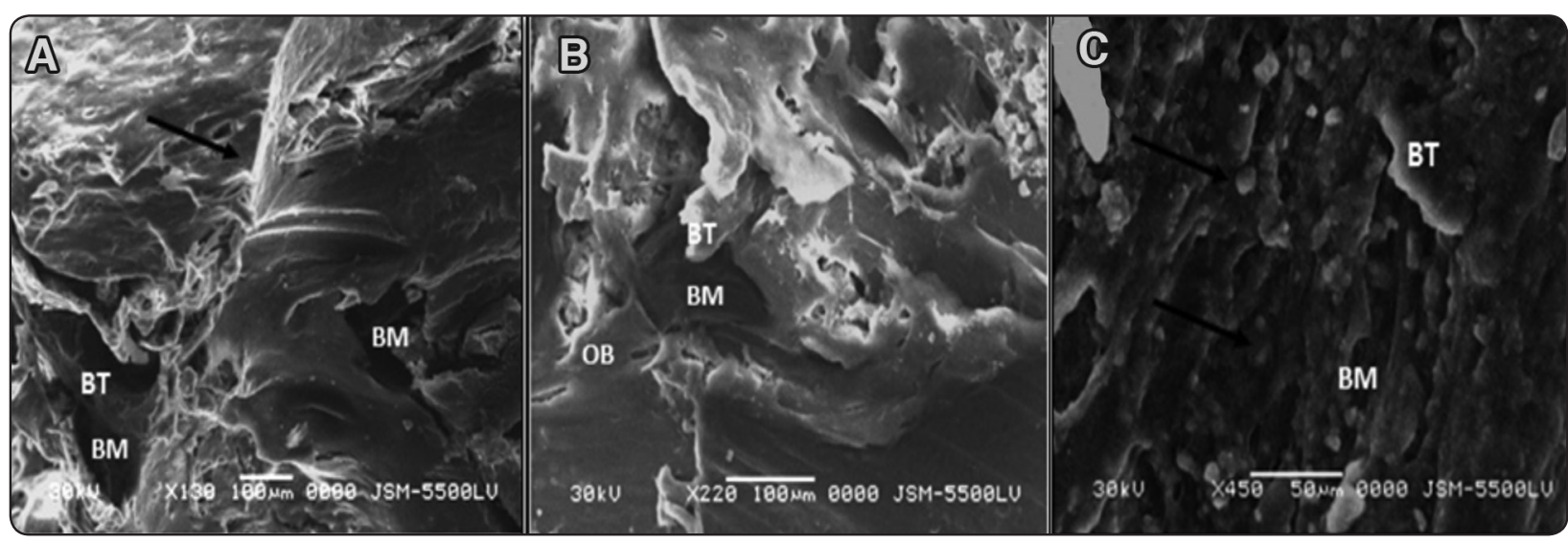

Fig. (17) Scanning electron micrograph of the control site of group III:; A.showing incomplete closure of the central area of the bone defect with new bone is seen continuous with original bone. Note long thin new bone trabecula (BT) and large bone marrow cavity (BM) in between. Note persistence of wide irregular areas of bone defect (arrow). B. shows irregularly formed bone trabeculae (BT)of varying thickness near by the original bone $(\mathrm{OB})$ and wide bone marrow cavities $(\mathrm{BM})$ in between. C shows bone trabeculae (BT), bone marrow cavity and globular calcification (arrow) (A x130, B x220, Cx 548).
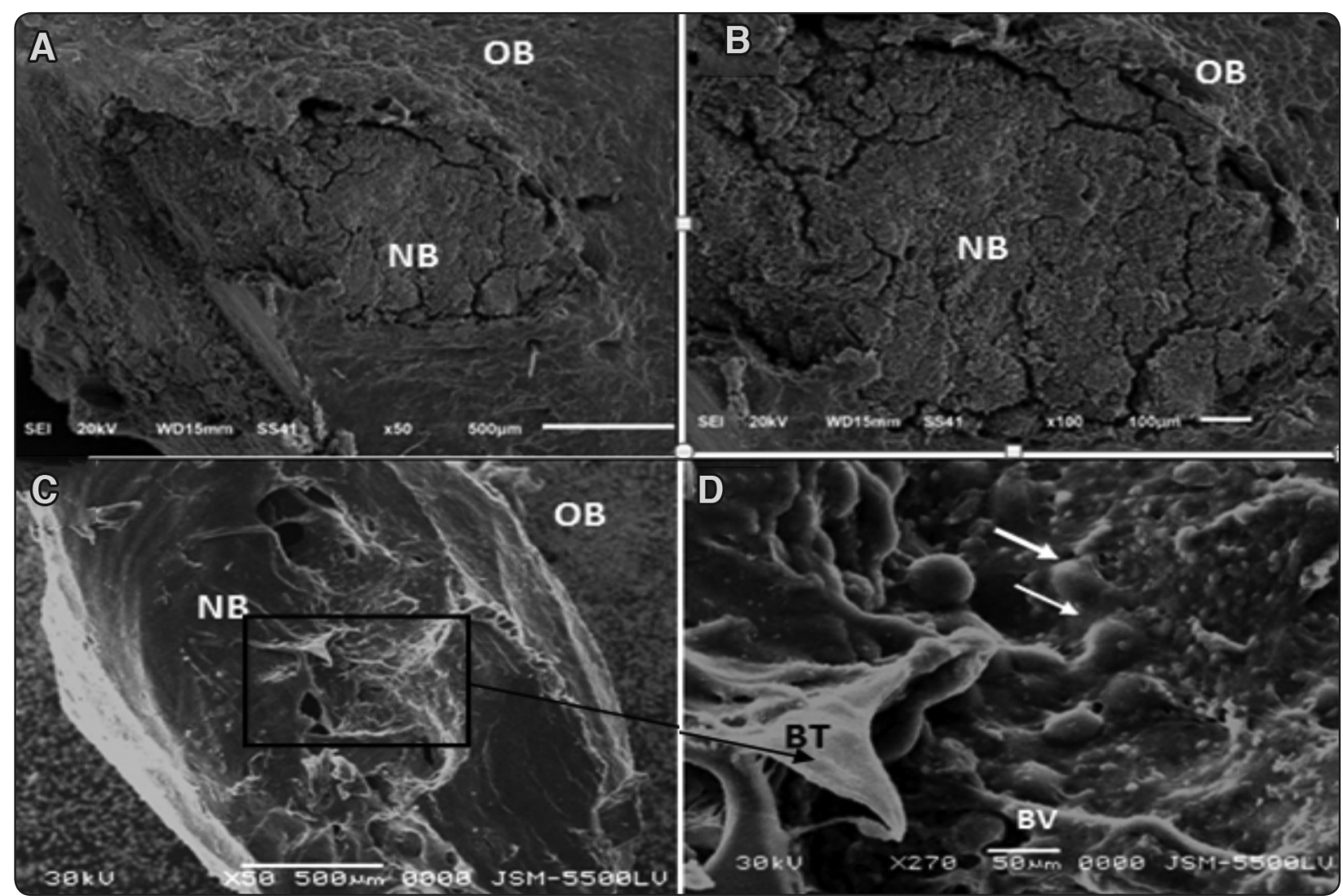

Fig. (18) Scanning electron micrograph of the experimental site of group III; A. and B. shows replacement of the graft material with new bone formation (NB) filling the bone defect with no demarcation line between it and the original bone (OB). C. shows replacement of the graft material with new bone formation (NB) filling the bone defect .D. Higher magnification of the previous field shows globular calcification (arrow), new bone trabeculae (NB) and blood vessel (BV) (AX50,BX100, C X 50 and DX270) 


\section{Statistical quantitative evaluation of the newly} formed bone:

The greatest mean value of quantitative measurement of newly formed bone was recorded in experimental side at $8^{\text {th }}$ week with the least value obtained in control side at the $1^{\text {st }}$ week. Analysis of variance (ANOVA) test revealed a highly significant difference between control \& experimental side ( $\mathrm{p}$-value $<0.003$ ). In addition to, experimental side in the three periods was showed higher mean value than their corresponding in control side (tab. 1) \& (fig.19).

\section{Statistical evaluation of cell counting:}

The greatest mean value of inflammatory cell counting was recorded in control sides at the $1^{\text {st }}$ week with the least value obtained in experimental side at the $8^{\text {th }}$ week. t-test revealed that the difference between control and experimental side was very highly statistically significant at $1^{\text {st }}$ week (tab. 2) (fig.20), while it was statistically significant at $4^{\text {th }} \&$ $8^{\text {th }}$ week (tab. 3\&4) (fig.21\&22).

The greatest mean value of osteoblasts cell counting was recorded in experimental side at the $1^{\text {st }}$ week with the least value obtained in control side at the same period. t-test revealed that the difference between control and experimental side was statistically significant at the $1^{\text {st }}$ week (tab. 2) (fig.20), highly statistically significant at the $4^{\text {th }}$ week (tab.3) (fig.21), but it was statistically nonsignificant at the $8^{\text {th }}$ week (tab. 4) (fig. 22).

TABLE (1) Statistical quantitative analyses of newly formed bone in control and experimental side at the $1^{\text {st }}, 4^{\text {th }} \& 8^{\text {th }}$ week.

\begin{tabular}{|c|c|c|c|c|c|c|}
\hline & $\begin{array}{c}1^{\text {st }} \text { week Exp. } \\
\text { side }\end{array}$ & $\begin{array}{c}4^{\text {th }} \text { week Exp. } \\
\text { side }\end{array}$ & $\begin{array}{c}8^{\text {th }} \text { week Exp. } \\
\text { side }\end{array}$ & $\begin{array}{c}1^{\text {st }} \text { week con. } \\
\text { side }\end{array}$ & $\begin{array}{c}4^{\text {th }} \text { week con. } \\
\text { side }\end{array}$ & $\begin{array}{c}8^{\text {th }} \text { week } \\
\text { con. side }\end{array}$ \\
\hline Mean & 306.5 & 380 & 650 & 106.5 & 154.5 & 263 \\
\hline S. D & 28.99 & 89.10 & 104.65 & 3.54 & 13.44 & 120.21 \\
\hline Max & 286 & 317 & 576 & 104 & 164 & 348 \\
\hline Min & 327 & 443 & 724 & 109 & \\
\hline p-value & \multicolumn{7}{|c|}{$<0.003^{* *}$} \\
\hline
\end{tabular}

** Highly significant

TABLE (2) t-test of the means of cell counting in control and experimental side at the group I ( $1^{\text {st }}$ week $)$.

\begin{tabular}{|c|c|c|c|}
\hline & $\begin{array}{c}\text { control } \\
\text { side }\end{array}$ & $\begin{array}{c}\text { experimental } \\
\text { side }\end{array}$ & P-value \\
\hline Inflammatory cells & $183 \pm 10.97$ & $23 \pm 19.86$ & $0.000^{* * *}$ \\
\hline Osteoblasts & $5 \pm 3.77$ & $39 \pm 17.96$ & $0.01^{*}$ \\
\hline Osteoclasts & $2 \pm 1.26$ & $1 \pm 0.96$ & 0.11 \\
\hline
\end{tabular}

***Very highly significant * significant

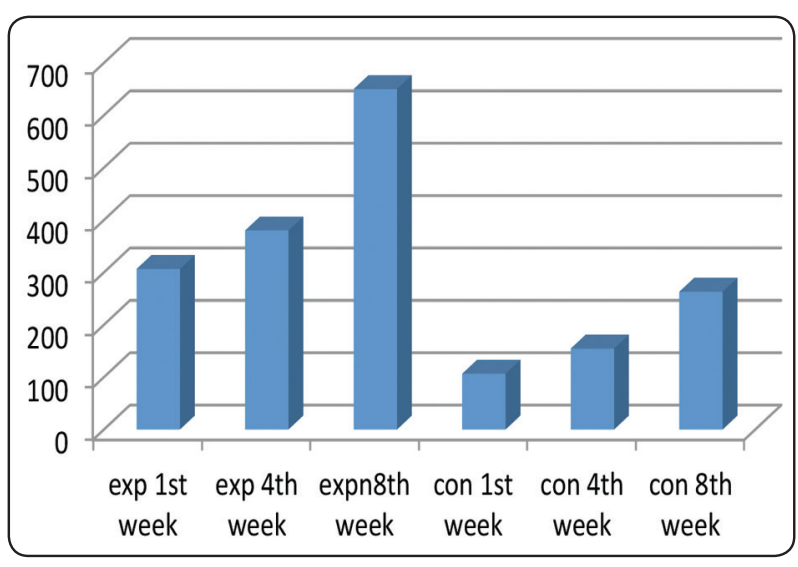

Fig. (19): Column chart representing mean of the quantitative measurement of newly formed bone in control and experimental side at the $1^{\text {st }}, 4^{\text {th }} \& 8^{\text {th }}$ week . 
The greatest mean value of osteoclasts cell counting was recorded in control and experimental sides at the $4^{\text {th }}$ week (tab.3) (fig.21). t-test revealed that the difference between control and experimental side was statistically non-significant at the $1^{\text {st }}, 4^{\text {th }} \&$ $8^{\text {th }}$ weeks (tab. 2,3\&4) .

The greatest mean values of inflammatory cells in experimental side were observed for lymphocytes, macrophages and plasma cells (chronic inflammatory cells) at the $1^{\text {st }}$ and $4^{\text {th }}$ weeks, with the least values of all types of inflammatory cells at the $8^{\text {th }}$ week. The greatest mean values of inflammatory cells in control side were observed for PMNLs (acute inflammatory cells) at the $1^{\text {st }}$ week, followed by lymphocytes at the $4^{\text {th }}$ and $8^{\text {th }}$ weeks, with the least values of all types of inflammatory cells at the $8^{\text {th }}$ week (tab. 5) (figs. $23 \& 24$ ).

TABLE (3) t-test of the means of cell counting in control and experimental side at group II ( $4^{\text {th }}$ week $)$

\begin{tabular}{|l|c|c|c|}
\hline & $\begin{array}{c}\text { control } \\
\text { side }\end{array}$ & $\begin{array}{c}\text { experimental } \\
\text { side }\end{array}$ & P-value \\
\hline inflammatory cells & $90 \pm 27.06$ & $28 \pm 4.16$ & $0.02^{*}$ \\
\hline osteoblasts & $13 \pm 9.26$ & $35 \pm 4.27$ & $0.005^{* *}$ \\
\hline osteoclasts & $3 \pm 1$ & $3 \pm 1.29$ & 1 \\
\hline
\end{tabular}

** Highly significant * significant

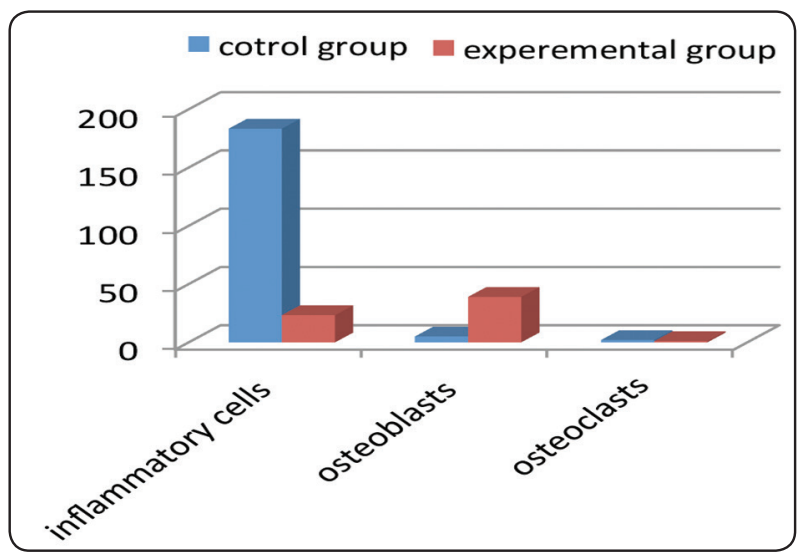

Fig. (20) Column chart representing mean cell counting in control and experimental side at group I (1st week).

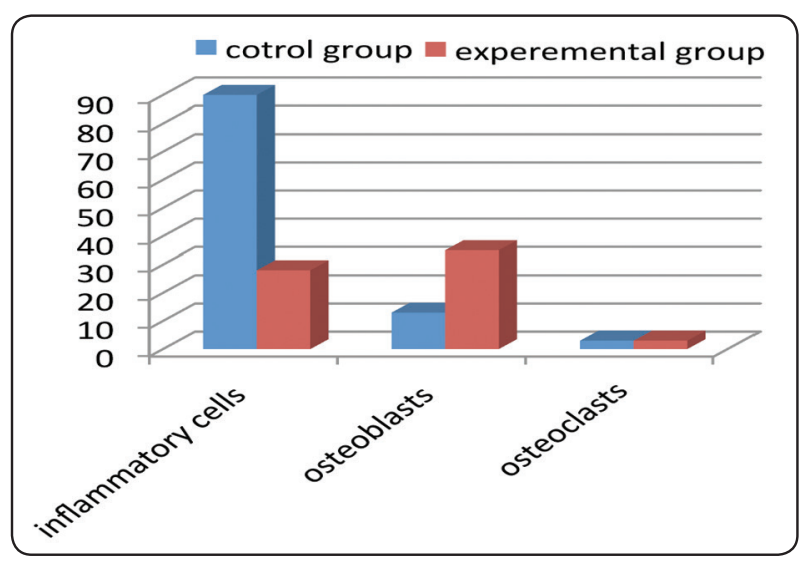

Fig. (21): Column chart representing mean cell counting in control and experimental side at group II (4th week).

TABLE (4) t-test of the means of cell counting in control and experimental side at group III ( $8^{\text {th }}$ week).

\begin{tabular}{|l|c|c|c|}
\hline & $\begin{array}{c}\text { control } \\
\text { side }\end{array}$ & $\begin{array}{c}\text { experimental } \\
\text { side }\end{array}$ & P-value \\
\hline inflammatory cells & $32 \pm 16.82$ & $3 \pm 0.58$ & $0.04^{*}$ \\
\hline osteoblasts & $21 \pm 5.97$ & $24 \pm 2.22$ & 0.4 \\
\hline osteoclasts & $2 \pm 1.89$ & $1 \pm 0.58$ & 0.1 \\
\hline
\end{tabular}

* Significant

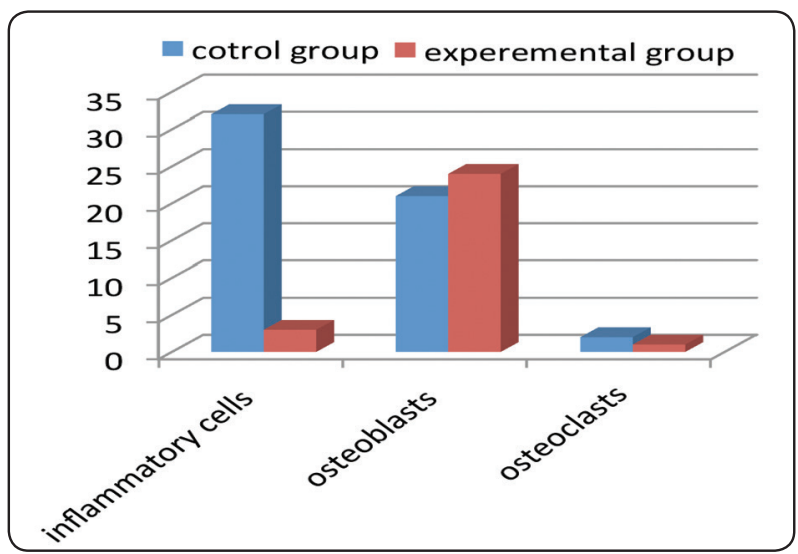

Fig. (22) Column chart representing mean cell counting in control and experimental side at group III (8th week). 
TABLE (5) The means of cell counting of different types of inflammatory cells in control and experimental side at the $1^{\text {st }}$ week, $4^{\text {th }}$ week $\& 8^{\text {th }}$ week

\begin{tabular}{|c|c|c|c|c|c|c|}
\hline & \multicolumn{4}{|c|}{ control group } & \multicolumn{4}{c|}{ experimental group } \\
\cline { 2 - 7 } & 1 st week & 4th week & 8th week & 1st week & 4th week & 8th week \\
\hline lymphoctes & 14 & 55 & 25 & 10 & 13 & 1 \\
\hline monocytes & 8 & 5 & 0 & 0 & 1 & 0 \\
\hline macrophages & 12 & 4 & 0 & 7 & 5 & 1 \\
\hline plasma cells & 21 & 10 & 3 & 2 & 6 & 1 \\
\hline PMNLs & 126 & 12 & 3 & 1 & 1 & 0 \\
\hline MNG.cells & 3 & 3 & 0 & 3 & 2 & 0 \\
\hline
\end{tabular}

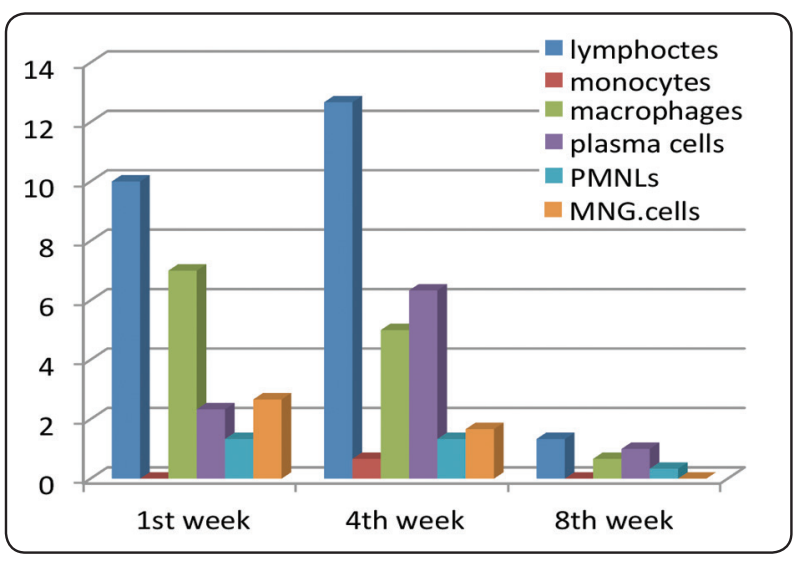

Fig. (23) Column chart representing mean cell counting of different types of inflammatory cells in experimental side at the $1^{\text {st }}, 4^{\text {th }} \& 8^{\text {th }}$ weeks.

\section{DISCUSSION}

The essential question that needs to be answered for the increasing number of biomaterials prior to contact with the human body is whether they are biocompatible or not. The biocompatibility remains the main theme for biomaterials applications in medicine and dental field. It is mostly accepted that this term means not only absence of a cytotoxic effect but also positive effects in the sense of bio-function replacement i.e. promotion of the biological processes which further the willful aim of the application of a biomaterial ${ }^{25}$.

The Biocompatibility of a dental material can be evaluated by variable methods, In general, they

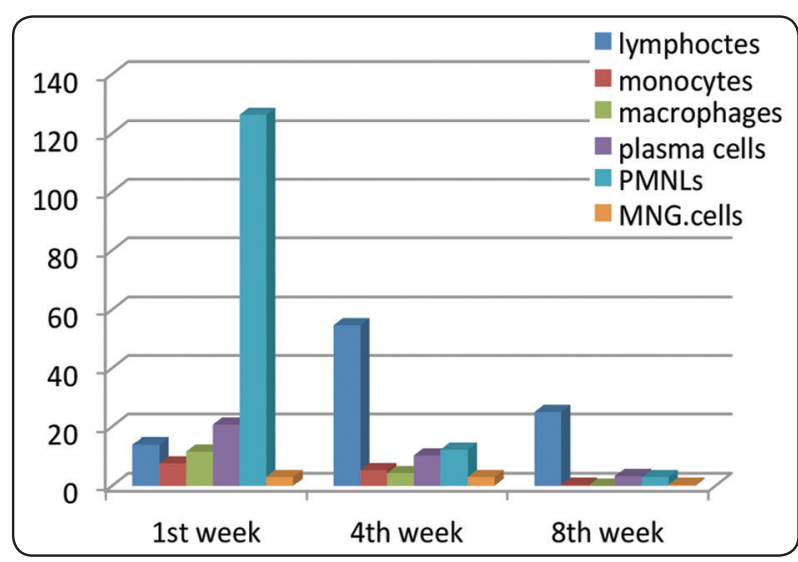

Fig. (24) Column chart representing mean cell counting of different types of inflammatory cells in control side at the $1^{\text {st }}, 4^{\text {th }} \& 8^{\text {th }}$ weeks.

are needs to be tested in three successive steps ${ }^{25}$. The first step is the in-vitro test with cell cultures. It provides rapid and inexpensive data. This test is necessary not only prior to application but also while designing the biomaterials in order to choose the most suitable one. The second step is the invivo test with animals, only performed with the final product. The last step is the clinical studies on human patients ${ }^{24,26}$.

Any in-vitro or in-vivo test should take the end-use application into account. Another basic requirement is to make sure that the data obtained in in-vitro tests are significant with regards to the much more complex in-vivo environment. Experimental studies have demonstrated a good correlation between 
in-vitro and in vivo tests ${ }^{27}$. In vitro, cells are generally more sensitive than in-vivo, therefore materials, which are harmless to the cells even in long-lasting assays are likely to be inert in-vivo ${ }^{28}$. Usage tests have been developed specifically for the evaluation of the biocompatibility of dental materials. The pulp and dentine test, the pulpotomy test and the endodontic usage test are widely recognized ${ }^{29}$.

The material of interest in this study (WPC) was tested in the last few years in different researches(5-10) most of these studies have been conducted in vitro, San M. et. al., ${ }^{30}$ examined the human pulp cells response to PC in vitro, De Deus G et.al., ${ }^{30}$ investigated the Cytotoxicity of MTA and PC on human endothelial cells. Limited studies have been carried out in vivo. Saidon J. et. $\mathrm{al}^{10}$, examined the cell and tissue reactions to MTA and PC, while Fabiano S. et. al, ${ }^{32}$ evaluate two type of PC in the skull of rats . Consequently, further research should concentrate on the in vivo situation to test the biocompatibility and the possibility of bone healing ability of WPC.

Nowadays, research involving experimental animals is recommended, but each animal has advantages and disadvantages depending on the experiment. When considering a recommended experimental model, the selected animal should show more similarity to humans. The ideal animal models are monkeys. However, these animals are difficult and expensive to acquire. With regard to the bone healing, the choice of rabbits as an animal model in our study has advantages such as suitable size, cost and easy handling. In addition, some similarities are reported in the bone mineral density and Haversian remodeling which occurs faster in rabbits $^{3,33}$

The present study evaluated the biocompatibility and the bone healing efficacy following the WPC graft material in experimentally created intrabony defects in rabbit's mandible. In this study the animals were euthanized for evaluation at 1,4 and 8 weeks after surgery, this research model was selected to be safe for the preservation and quality of animal's life until the end of the evaluation period. This type of model was used by different experimental research $^{34-37}$. Lower border of the mandible was selected due to ease accessibility and the reasonable size $^{37}$.

Due to the diversity of adverse biological effects which might be caused by dental materials, and to better understand issues and perspectives of in vivo biocompatibility testing of graft biomaterials, the biocompatibility assessment cannot rely on a single test but has to be based on a planned and structured approach (concept), and a fundamental understanding of the inflammatory and wound healing responses is necessary ${ }^{39,40}$. Therefore, this research examined the histological process of healing and the quantitative measurement of newly formed bone and cell counting. The histology is the most powerful method to evaluate the healing of bone defects, and considered a direct method for testing the biocompatibility ${ }^{40}$. Another commonly used method for supporting the histological finding is the scanning electron microscopic SEM ${ }^{42,43}$.

Thehistological resultsof thepresentinvestigation revealed that after one week in experimental side newly formed bone trabeculae were observed extended on a radiating manner from the old bone toward the center of the bony defect. Graft material was surrounded by moderate inflamed high cellular CT with collagen fibers and bone spicules. While in control side granulation tissue was appeared filling the bony defect in most of the specimens, except small areas of osteoid tissue lining the wall of the defect. Other areas showed excessive osteoclastic activity. These finding were confirmed by the SEM, the experimental defect appeared filled with fused amalgamated graft material with new bone formation lining the cavity and union of the old bone with new one at several points. Persistence of a wide cavity in the control defect with irregular 
edges was appeared. These histological and SEM results were supported by Neto, Silva, et al., ${ }^{44}$ who found that no significant differences in the amount of newly formed bone between PC and MTA in the repair of furcation perforations in dogs.

After four weeks the experimental defect, histologically showed well organized bone trabecula were observed filling large areas of the bony defect, they were lined by active osteoblasts. Large bone marrows cavities were filled with C.T and large blood vessels and small remnant of graft material. The amount and size of bone trabeculae were increased at the $8^{\text {th }}$ weeks with disappearance of graft material. This result was compatible with SEM, indicating possible use of WPC as bone substitute, as founded by Dokami S. et. al., ${ }^{14}$ new bone formation was observed which was characterized by osteoid formation, osteoblastic rimming, and formation of new bone trabeculae around a surgically created bony cavity in mandible of a dog filled with accelerated PC.

The rate of bone formation in control defect was delayed, as only few new bone trabeculae were observed at central area and the lateral wall of the bony defect with areas of fat tissue at four weeks. These bone trabeculae were limitedly increased in the $8^{\text {th }}$ week with presence of large areas of fat tissue. This delaying in bone healing in control side was confirmed by other studies ${ }^{45,46}$.

The Histomorphometric analysis of bone healing and cell count in the current study provided for a quantitative evaluation of WPC biocompatibility and can also be utilized to determine the potency of this material in bone healing. Histomorphometric analysis confirmed the light and scanning electron microscopic results. All experimental periods examined in this study displayed evidence of new bone formation, with statistically significant difference in the amount of new bone formation was found between experimental and control sides. The greatest mean value of quantitative measurement of newly formed bone was recorded in experime ${ }^{47}$ had the similar result of pulpal tissue repair with hard tissue formation when they used white MTA, WPC and Beta tricalcium phosphate on pulpotomized primary teeth of pigs.

Successful and similar type of bone repair found in deliberately perforated dog's teeth using WPC, PC Type II, Type V, and MTA (as control). Histological analysis showed no significant differences in the amount and histology of newly formed bone in all materials ${ }^{44}$. Moreover, it has also been shown that PC contains the basic elemental composition of MTA, except the presence of bismuth oxide ${ }^{48}$ and considerable levels of calcium oxide which has an important role on tissue biological response from its conversion into calcium hydroxide and, consequently, stimulating tissue mineralization ${ }^{49}$

These Histomorphometric results proved by the cell counting analysis where the greatest mean value of osteoblasts cell counting was recorded in experimental side at the $1^{\text {st }}$ week with the least value obtained in control side at the same period. This result confirming the higher rate of bone formation in experimental side than control one proving the role of WPC in introducing a good alkaline media, good adherence and proliferation media of the cells as supported by Saidon $\mathrm{J}$ et.al ${ }^{10}$ and Abdullah D et.al. ${ }^{13}$.

The greatest mean value of osteoclasts cell counting was recorded in control and experimental side at the $4^{\text {th }}$ week.t-test revealed that the difference between control and experimental side was statistically non-significant at the $1^{\text {st }}, 4^{\text {th }} \& 8^{\text {th }}$ week. In the same time the inflammatory cell count was decreased at the $4^{\text {th }}$ week. This result indicating the high rate of bone remodeling which occurs faster in rabbits as reported by ${ }^{3,33}$.

Statistical analysis of inflammatory cell count revealed the greatest mean value in control sides at the $1^{\text {st }}$ week with the least value obtained in experimental sides at the $8^{\text {th }}$ week. T-test revealed 
that the difference between control and experimental sides was very highly statistically significant especially at $1^{\text {st }}$ week, while it was statistically significant at $4^{\text {th }} \& 8^{\text {th }}$ week. This indicating the suitable alkaline PH obtained by WPC which allowing a suitable media for forming cell growth, and least irritation leading to the lower inflammatory cell reaction especially at the early periods of bone healing, this indicating the biocompatibility of WPC. This explanation is in agreement with those reported in previous studies ${ }^{13,50}$.

These results demonstrate the safety of the WPC regarding degradation and biocompatibility. These also were explained by previous studies ${ }^{51,52}$. They stated that PC is bioactive material, the biocompatibility of the materials had originally been attributed to the chemical similarity to tooth hard tissues namely calcium phosphate. In an another experiment, Chinese hamster ovary cells were exposed to MTA and white PC at a concentration ranging from 1 to $1000 \mu \mathrm{g} / \mathrm{mL}$ for $1 \mathrm{~h}$ at $37^{\circ} \mathrm{C}$. MTA and PC did not show genotoxic effects in all concentrations evaluated and no significant differences in cytotoxicity were observed in MTA and $\mathrm{PC}^{12}$.

In the current study, only one experimental specimen showed severe type of inflammation, with foreign body reaction. But the rest of the specimen did not show that. Type of inflammatory cells revealed a great difference between control and experimental side especially at the 1 st week. The acute inflammatory cells were the prominent type particularly the PMNLs in control sides; while the chronic inflammatory cells were the prominent type mainly lymphocytes and macrophages in experimental sides. These inflammatory results was reported by Bidar, Maryam, et al.,$^{53}$ who founded that no acute inflammation in any of his specimens, only Chronic inflammation in white and gray MTA and white and gray PC was appeared.
All the result of this study showed a pattern of bone formation in PC graft material similar to the result of other studies testing a large number of grafts $^{54-56}$. This pattern of bone formation which start from the wall of the bone defect toward the center, suggests that the PC material is biocompatible and osteoconductive. Osteoconduction is due to the fact that the material promotes an alkaline $\mathrm{pH}$ and releasing of calcium and phosphate elements that stimulate the calcification process, with absence of foreign body reaction and account for the basic mechanisms of physicochemical healing of hard tissue $^{50}$. At present several researches establish that PC is similar to some commercially available graft material in its basic composition, physical, chemical characteristics, and in biocompatibility ${ }^{57}$.

Several publications showed that PC and MTA are equally biocompatible. Tissue reaction of MTA and $\mathrm{PC}$ are tested through bone implantations of freshly mixed MTA and PC in bony cavities of the mandibles of guinea pigs and this mix is also added to culture plates. When evaluated in both vitro and in vivo tests, MTA, and PC showed comparative biocompatibility ${ }^{10}$. MTA and PC were interacted with endothelial cells to evaluate their cytotoxic level. Both materials showed an initial mild cytotoxic activity which reduced with time ${ }^{31}$.

Also the present study results were supported by the Min KS.et. al., ${ }^{58}$ investigation which transacted with the cellular effects of PC on cultured human pulp cells, no cytotoxicity was observed in the PC. Whereas in the same study other materials like Dycal, glass ionomer cement, and intermediate restorative material showed cellular survival rate was less than $40 \%$ on direct contact with pulp cell. In addition to the better biocompatibility of PC, this study showed that it allows the expression of mineralization related genes on cultured human pulp cells, and has the potential to be used as a proper hard tissue developing material in dental treatment. 


\section{CONCLUSION}

Based on results in the current study, it can be concluded that WPC is a biocompatible material under the restriction of this study. Also it is can be used as a suitable cheaper alternative dental material and a cheaper bone graft material easily sterilized, but further studies should be carried out to ensure its safety as a bone graft material. This may open the way for a cheaper graft material, which will certainly benefit millions of people in future, especially most of the patients in developing countries, who cannot bear the cost of commercial used bone graft material.

\section{REFERENCES}

1- Polyzois G L: In vitro evaluation of dental materials. Clinical materials.:16: 21-60-.1994

2- Unal GC, Maden M, Isidan T: Repair of Furcal Iatrogenic Perforation with Mineral Trioxide Aggregate: Two Years Follow-up of Two Cases. Eur J Dent. 4:475-481 .- 2010:

3- Campello R I C, Vasconcelos B C E, SampaioI G C, Rolim A, Porto GG : The use of Portland cement in the repair of mandibular fractures in rats. Acta Cirurgica Brasileira:26: 426-432. 2011

4- Tolentino E, Lameiras FS, Gomes AM, Silva CAR, Vasconcelos WL: Effects of high temperature on the residual performance of Portland cement concretes. Mat Res.:5: 301-307. 2002

5- Deal BF, Wenckus CS, Johnson BR, Fayad MI: Chemical and physical properties of MTA, Portland cement and a new experimental material, fast-set MTA. J Endod. :28 :252-256. 2002

6- Bye Gerry C. Portland cement: composition, production and properties. Thomas Telford, 1999.

7- Holland R, De Souza V, Murata S S, Nery M J, Bernabé P F, Otoboni Filho JA, Dezan Júnior E: Healing process of dog dental pulp after pulpotomy and pulp covering with mineral trioxide aggregate or Portland cement. Braz Dent J.:12:109-113. 2001

8- Menezes R, Bramante CM, Letra A, Carvalho VG, Garcia RB: Histologic evaluation of pulpotomies in dog using two types of mineral trioxide aggregate and regular and white portland cements as wound dressings. Oral Surg Oral Med Oral Pathol Oral Radiol Endod .:98: 376-379. 2004

9- Trindade AC, Oliveira EP, Figueiredo JÁ. Comparative analysis of the tissue response to mineral trioxide aggregate(MTA), Portland cement and Portland cement to radiopaque substance. J Bras Endod.:4:309-314. 2003

10- Saidon J, He J, Zhu Q, Safavi K, Spångberg LS: Cell and tissue reactions to mineral trioxide aggregate and Portland cement. Oral Surg Oral Med Oral Pathol Oral Radiol Endod.:95: 483-489. 2003

11- Funteas UR, Wallace JA, Fochtman EW: A comparative analysis of mineral trioxide aggregate and Portland cement. Aust Endod J.: 29:43-44. 2003

12- Ribeiro CS, Kuteken FA, Hirata Júnior R, Scelza MFZ: Comparative evaluation of antimicrobial action of MTA, calcium hydroxide and Portland cement. J Appl Oral Sci.:14:330-333. 2006

13- Abdullah D, Ford T R, Papaioannou S, Nicholson J, McDonald F: An evaluation of as a restorative material. Biomateria.:23: 4001-4010. 2002

14- Dokami S, Raoofi S, Mohamad J, Hooman K. Histological analysis of the effect of accelerated portland cement as a bone graft substitute on experimentally-created threewalled intrabony defects in dogs. J Dent Res Dent Clin Dent Prospects.:1:131-136. 2007

15- Ravi . KS, Vanka A, Shashikiran N. Portland cement: A Building of Evidence for Clinical Use. Int J Dent Clin.; 3:52-55, 2011

16- Arnbjerg J: Clinical use of ketamine-xylazine for anaesthesia in the cat. Nord Vet Med.:31:145-154. 1979

17- Mohammad K, Mehrnaz S S, Maryam A, Mehrnoosh S S: Influence of local anesthetics with or without epinephrine 1/80000 on blood pressure and heart rate: A randomized double-blind experimental clinical trial. Dent Res J (Isfahan).:9 : 437-440.2012

18- Callis GM: Bone, Ch:18 in Bancroft J D and Gamble M (eds), Theory and practice of histological techniques. 6th Ed, Churchill Livingstone,:333- 364. 2008

19- Schneider, C. A.; Rasband, W. S. \& Eliceiri, K. W., "NIH Image to ImageJ: 25 years of image analysis", Nature methods 9(7): 671-675, 2012

20- Lai S, Zhou X: Inflammatory cells in tissues of gout patients and their correlations with comorbidities. Open Rheumatol J.:7: 26-31. 2013 
21- Ørstavik D, Mjör I A: Usage test of four endodontic sealers in Macaca fascicularis monkeys. Oral surgery, oral medicine, oral pathology.:73: 337-344. 1992

22- Mould R: Introductory medical statistics. 2nd Ed. Adam Hilger, Bristol and Philadelphia,:17, 22 ,126 . 1989

23- Bozzola J J and Russel L D: Electron Microscopy Principles and Techniques for Biologists, 2nd Ed, Jones and Bartlett Publisher, Boston.: 51-69. 1999

24- Kirkpatrick C J, Bittinger F, Wagner M, Köhler H van Kooten T G, Klein C L, Otto M: Current trends in biocompatibility testing." Proceedings of the Institution of Mechanical Engineers, Part H: Journal of Engineering in Medicine. :212: 75-84. 1998

25- Wintermantel E, Shah-Derler B, Bruinink A, Petimermet M, Blum J, Ha SW: Biokompatibilität in: Wintermantel E, Ha S-W (eds), Medizin technik mitbiokompatiblen Werkstoffen und Verfahren, 3 Ed. Springer Verlag,: 5-44. 2002

26- Rosen E: Development of an In-Vitro Biocompatibility Test for Materials with Respect to its Applicability for the Implantable Direct Glucose Fuel Cell. Qween Marry University of London.:1-82. 2006 (Diploma thesis).

27- Northup SJ, Cammack JN. Mammalian cell culture models. InHandbook of biomaterials evaluation. Scientific, technical, and clinical testing of implant materials. Macmillan New York, NY. :209-225. 1986

28- Ciapetti G, Granchi D, Arciola CR, Cenni E, Savarino L, Stea $S$, et al: In Vitro Testing of Cytotoxicity of Materials. In: Wise DL (ed). Biomaterials and Bioengineering Handbook. Marcel Dekker Inc,:179-198. 2000

29- Browne R M: Animal tests for biocompatibility of dental materials-relevance, advantages and limitations. J dent.:22: S21-S24. 1994

30- San M, Hyun-Il K, Hyo-JP, Sung-H Pi, Chan-Ui Hong: Human pulp cells response to portland cement in vitro. $\mathrm{J}$ Endod.:33:163-166. 2007

31- De Deus G, Ximenes R, Gurgel-filho E, Plotkowski M, CoutinhoFilho T: Cytotoxicity of MTA and Portland cement on human ECV304 endothelial cells. Int Endod J.: 38:604-609. 2005

32- Fabiano S, Jose Carlos C, Reinaldo D. Macroscopic and microscopic evaluation of Portland Cement Joint - CP I and the Portland Cement White not structural - CPB included in the skull of rats, Brazil, university of saopaulo: Faculdade de Odontologia (FO). 2009(Master theses).
33- Hohl TH, Shapiro PA, Moffett BC, Ross A. Experimentally induced ankylosis and facial asymmetry in the macaque monkey. J maxillofac surg.:9:199-210. 1981

34- Betoni-Junior W, Dechichi P, Esteves JC, Zanetta-Barbosa D, Magalhães AE. Evaluation of the bone healing process utilizing platelet-rich plasma activated by thrombin and calcium chloride: a histologic study in rabbit calvaria. J Oral Implantol.: 39:14-21. 2013

35- Stein, LE, Pijanowski GJ, and Johnson AL. "A histological evaluation of rabbit tendons sutured using the Bunnell pattern." Veterin Surg. :14: 145-148. 1985

36- Ma JH, Guo WS, Li ZR, Wang BL. Local Administration of Bisphosphonate-soaked Hydroxyapatite for the Treatment of Osteonecrosis of the Femoral Head in Rabbit. Chin Medic J.:129:2559-2566. 2016

37- Yang X, Li Y, Huang Q, Yang J, Shen B, Pei F. Evaluation of a biodegradable graft substitute in rabbit bone defect model. Indian J Orthopaed.:46:266-273. 2012

38- Miloro, M., Haralson, D. J., \&Desa, V. Bone Healing in a Critical-Size Defect Using Platelet-Rich Plasma. indigo. lib.uic.edu. 2010.

39- Anderson JM. In vivo biocompatibility of implantable delivery systems and biomaterials. Euro j pharmaceu \& biopharmac.:40:1-8. 1994

40- Schmalz G. Concepts in biocompatibility testing of dental restorative materials. Clinic oral investig.:25:154-162. 1998

41- Ross MH, Romrell LJ, Kaye GI. Histology - a text and atlas. 3rd ed. Baltimore, MD: Williams \& Wilkins. 1995

42- Listgarten MA, Buser D, Steinemann SG, Donath K, Lang NP, Weber HP. Light and transmission electron microscopy of the intact interfaces between non-submerged titaniumcoated epoxy resin implants and bone or gingiva. J Dent Res.:71:364-371. 1992

43- Hollinger JO, Kleinschmidt JC. The critical size defect as an experimental model to test bone repair materials. J Craniofac Surg.:1:60-68. 1990

44- Neto S, Schnaider TB, Gragnani A, Paiva AP, Novo NF, Ferreira LM. Portland cement with additives in the repair of furcation perforations in dogs. Acta Cirurgica Brasileira.:27:809-814.2012

45- Saad KA, Abu-Shahba AG, El-Drieny EA, Khedr MS. Evaluation of the role of autogenous bone-marrow-derived 
mesenchymal stem cell transplantation for the repair of mandibular bone defects in rabbits. J Cranio-Maxillofac Surg.:43:1151-1160. 2015

46- Cheng G, Li Z, Wan Q, Lv K, Li D, Xing X, Li Z. A novel animal model treated with tooth extraction to repair the full-thickness defects in the mandible of rabbits. J Surg Res.:194:706-716. 2015

47- Shayegan A, Petein M, Abbeele AV. Beta-tricalcium phosphate, white mineral trioxide aggregate, white Portland cement, ferric sulfate, and formocresol used as pulpotomy agents in primary pig teeth. Oral Surg Oral Med Oral Pathol Oral Radiol Endod.:105:536-542. 2008

48- Estrela C, Bammann LL, Estrela CR, Silva RS, Pécora JD. Antimicrobial and chemical study of MTA, Portland cement, calcium hydroxide paste, Sealapex and Dycal. Braz Dent J.:11:3-9. 2000

49- Estrela C, Sousa-Neto MD, Guedes OA, Alencar AH, Duarte MA, Pécora JD. Characterization of calcium oxide in root perforation sealer materials. Braz Dent J.:23:539546. 2012

50- Asgary S, Eghbal MJ, Parirokh M, Ghoddusi J, Kheirieh S, Brink F. Comparison of mineral trioxide aggregate's composition with Portland cements and a new endodontic cement. J Endodon.:35:243-250. 2009

51- Camilleri J, Montesin F, Brady K, Sweeney R, Curtis R, Pitt Ford TR. A review of the methods used to study biocompatibility of Portland cement-derived materials used in dentistry. Malta Med J.:18:9-14. 2006
52- Goel M, Bala S, Sachdeva G. Comperative Evaluation Of MTA, Calcium Hydroxide And Portland Cement As A Root End Filling Materials: A Comprehensive Review. Indian J Dent Scienc.:3:83-88. 2011

53- Bidar M, Naghavi N, Mohtasham N, Sheik-Nezami M, Fallahrastegar A, Afkhami F, Mashhadi NA, Nargesi I. Mineral trioxide aggregate and portland cement for direct pulp capping in dog: a histopathological evaluation. J Dent Res, Dent Clin, Dent Prosp.:8:134-140. 2014

54- Gutierres M, Hussain NS, Lopes MA, Afonso A, Cabral AT, Almeida L, Santos JD. Histological and scanning electron microscopy analyses of bone/implant interface using the novel Bonelike ${ }^{\circledR}$ synthetic bone graft. J Orthopaed Res.:24:953-958. 2006

55- Duarte F, Lopes MA, Santos JDBonelike1 composites for the regeneration of bone lesions. Mater Sci Forum . 455:370-373, 2004.

56- Lobato JV, Sooraj Hussain N, Botelho CM, Rodrigues JM, Luis AL, Maurício AC, Lopes MA, Santos JD. Assessment of the potential of Bonelike ${ }^{\circledR}$ graft for bone regeneration by using an animal model. InKey Eng Mater.:284:877-880. 2005

57- Chakraborty A. Will portland cement be a cheaper alternative to mineral trioxide aggregate in clinical use? A comprehensive review of literature. Int J Contemp Dent Med Rev. 2015.

58- Min KS, Kim HI, Park HJ, Pi SH, Hong CU, Kim EC. Human pulp cells response to Portland cement in vitro. J Endod.:33:163-166. 2007 